\title{
FORMULASI SEDIAAN GEL MINYAK ATSIRI DAUN CENGKEH \\ (Syzygium aromaticum (L.) Merr. \& L.M.Perry) SEBAGAI ANTISEPTIK TANGAN DAN UJI DAYA HAMBAT TERHADAP BAKTERI Staphylococcus aureus
}

\section{GEL FORMULATIONS OF ESSENTIAL OIL OF CLOVE (Syzygium aromaticum (L.) Merr. \& L.M.Perry) LEAVES AS HAND ANTISEPTICS AND INHIBITORY TEST AGAINST Staphylococcus aureus}

\author{
Iffani Fardan, Sabtanti Harimurti \\ Program Studi Farmasi, Fakultas Kedokteran dan Ilmu Kesehatan, \\ Universitas Muhammadiyah Yogyakarta, \\ Kampus Terpadu UMY, Jl. Brawijaya, Kasihan, Bantul, Yogyakarta 55183 \\ Email: sabtanti@umy.ac.id (Sabtanti Harimurti)
}

\begin{abstract}
ABSTRAK
Kandungan utama dari minyak daun cengkah adalah eugenol yang mempunyai aktifitas sebagai antibakteri. Berdasarkan aktivitasnya tersebut, eugenol digunakan untuk membuat gel antiseptik dalam penelitian ini. Hal ini dilakukan dengan harapan akan bisa dikembangkan sebagai gel antiseptik tangan alternatif, menggantikan gel antiseptik tangan yang ada di pasaran yang sebagian besar bahan utamanya adalah alkohol yang masih menjadi perhatikan karena sifat nonhalalnya bagi masyarakat muslim. Penelitian ini bertujuan untuk memformulasikan eugenol menjadi gel antiseptik tangan yang memenuhi standar yang sudah ditentukan. Gel diformulasi dengan basis dasar CMC-Na dengan berbagai konsentrasi minyak atsiri daun cengkeh yaitu $0 \%$ (kontrol negatif), 1 , 10, dan $20 \%$. Evaluasi gel yang dilakukan pada peneltian ini adalah sifat fisik gel seperti evaluasi organoleptik, homogenisitas, $\mathrm{pH}$, daya lekat, daya sebar, dan viskositas. Selain itu dilakukan uji daya antibakteri untuk mengetahui seberapa besar konsentrasi minyak atsiri yang bisa digunakan untuk bisa menggantikan gel antiseptik tangan yang beredar di pasaran. Berdasarkan data penelitian, semakin besar konsentrasi minyak atsiri daun cengkeh yang digunakan, akan berpengaruh terhadap sifat fisiknya. Selain itu, dari penelitian ini diketahui bahwa konsentrasi minyak atsiri daun cengkeh yang mampu menghambat bakteri Staphylococcus aureus adalah sebesar 10\%, karena pada konsentrasi ini daya hambat yang dihasilkan setara dengan daya hambat yang dihasilkan oleh gel antiseptik tangan yang dijual di pasaran.
\end{abstract}

Kata kunci: gel antiseptik, minyak atsiri daun cengkeh. 


\begin{abstract}
The main component of the essential oil of clove leaves is eugenol. The eugenol has a pharmacological activity as an antibacterial. Based on this activity, eugenol was formulated for hand antiseptic gel. This is done with the hope for developing an alternative hand antiseptic gel to replace the existing hand antiseptic gel available in the market. Most of the hand antiseptic gel in the market containing alcohol as the active ingredient. Alcohol is still to be a concern for moslem community regarding to its nonhalal issue. The objective of this study was to formulate the eugenol to be a hand antiseptic gel that meets the gel standard. The gel was formulated using CMC-Na as the basic gelling agent. The concentrations of clove leaves essential oil that was used were $0 \%$ (negative control), 1, 10, and 20\%, respectively. Evaluation of the gel were the physical properties of gel such as organoleptic evaluation, homogeneity, $\mathrm{pH}$, adhesion, dispersion, and viscosity. In addition, the antibacterial activity test was conducted to determine the concentration of essential oils that can be used to inhibit bacterial growth as strong as hand antiseptic gel that is available in the market. Based on the research data, the increase of the concentration of clove leaves essential oil affects the physical properties of gel. In addition, from this study it can be proposed the concentration of essential oils from clove leaves are 10\%, since this concentration resulted in the inhibition to the growth of Staphylococcus aureus as strong as hand antiseptic gel that is available in the market.
\end{abstract}

Key words: antiseptic gel, essential oil of clove. 


\section{Pendahuluan}

Kesehatan merupakan aspek yang sangat penting bagi kehidupan. Memelihara kebersihan tangan merupakan salah satu hal yang sangat penting dalam menjaga kesehatan. Masyarakat sering tidak sadar bahwa dalam beraktivitas, tangan akan terkontaminasi mikroba yang akan mengganggu kesehatan (Radji, 2010). Kontaminasi bisa diperoleh dari beberapa tempat terutama tempattempat umum dan fasilitas umum lain yang memungkinkan menjadi tempat berkembang biaknya mikroba (Shu, 2013). Penyebaran mikroba salah satunya melalui tangan. Namun, kesadaran masyarakat tentang pentingnya kebersihan tangan terkadang masih kurang. Hal tersebut mungkin disebabkan karena malas mencuci tangan ataupun tidak sempat mencuci tangan dikarenakan susahnya memperoleh air untuk mencuci tangan atau air yang tersedia tidak bersih. Beberapa peneliti sudah melaporkan tentang pentingnya cuci tangan terhadap kesehatan, di antaranya seperti uraian berikut. Resiko terkena penyakit diare bisa diminimalisasi sampai $42-47 \%$ dengan mencuci tangan dengan menggunakan antiseptik seperti sabun
(Curtis and Cairncross, 2003; Luby et al., 2005). Luby et al. pada tahun 2011 melaporkan bahwa mencuci tangan dapat menurunkan resiko diare pada anak-anak di Bangladesh. Aiello et al. (2008) dan Biran et al. (2014) juga melaporkan bahwa mencuci tangan dapat mengurangi resiko diare dan ISPA. Selain itu mencuci tangan dapat mencegah cacingan seperti yang dilaporkan oleh Bieri et al. (2013) dan Umar (2008).

Sekarang ini sering digunakan antiseptik tangan untuk mengganti cuci tangan ketika tidak dijumpai air, seperti ketika dalam perjalanan. Bentuk sediaan antiseptik yang umum dijumpai di pasaran bisa berupa cairan atau gel. Bentuk gel lebih banyak dipilih karena tidak mudah tumpah ketika dibawa dalam perjalanan dibandingkan bentuk cairan. Bahan aktif pada gel yang sering dijumpai di pasaran adalah etanol. Etanol pada pemakaian berulang menyebabkan kekeringan dan iritasi pada kulit. Mengingat efek etanol yang tidak baik bila dipakai berulang, maka pencarian bahan aktif alternatif yang alami perlu dilakukan.

Pada penelitian ini dilakukan formulasi dan uji daya antibakteri dari gel minyak atsiri daun cengkeh terhadap 
bakteri Staphylococcus aureus, yaitu bakteri yang sering dijumpai di permukaan tangan dan dalam kondisi tertentu bisa menginfeksi manusia. Minyak atsiri daun cengkeh dipilih karena cengkeh merupakan salah satu komoditas pertanian yang sangat melimpah di Indonesia.

\section{Metode Penelitian}

\section{Alat dan Bahan}

Peralatan yang digunakan adalah timbangan analitik (Mettler Toledo ${ }^{\circledR}$ ), aluminium foil, gelas ukur (Iwaki pyrex), gelas piala, waterbath $\left(\right.$ Memmert $\left.^{\circledR}\right)$, pot gel, $\mathrm{pH}$ indikator, kaca preparat, mortir, stamper, cawan petri (Iwaki pyrex ${ }^{\circledR}$ ), pipet tetes, oven, laminar air flow (LAF), autoklaf, sarung tangan, masker, viskometer (Brookfield DV2T ${ }^{\circledR}$ ), anak timbang (protinal ${ }^{\circledast}$ ), dan gelas timbang. Bahan yang digunakan ialah minyak atsiri daun cengkeh berasal dari Palu (Sulawesi Tengah), Staphylococcus aureus FNCC 0047, $\mathrm{CMC}-\mathrm{Na} \quad\left(\right.$ Brataco $\left.^{\circledR}\right)$, gliserin $\left(\right.$ Brataco $\left.^{\circledR}\right)$, propilenglikol $\left(\right.$ Brataco $\left.^{\circledR}\right)$, akuades (Brataco $\left.{ }^{\circledR}\right), \mathrm{TSA}, \mathrm{BHI}, \mathrm{NaCl} 0,9 \%$, gel antiseptik di pasaran (Carex $\left.{ }^{\circledR}\right)$.

Pembuatan Formula Sediaan Gel

Formula standar yang digunakan dalam pembuatan gel dengan basis CMC-Na adalah berdasarkan penelitian Maswadeh et al. (2006) dengan variasi konsentrasi minyak atsiri daun cengkeh sebesar 0, 1, 10, dan 20\%. Adapun formula gel yang dibuat dapat dilihat pada Tabel 1.

Tabel 1. Formula gel antiseptik minyak atsiri daun cengkeh

\begin{tabular}{lcccc}
\hline \multicolumn{1}{c}{ Bahan } & F1 & F2 & F3 & F4 \\
\hline Minyak atsiri daun cengkeh $(\mathrm{g})$ & 0 & 0,3 & 3 & 6 \\
CMC-Na (g) & 1,5 & 1,5 & 1,5 & 1,5 \\
Gliserin (g) & 3 & 3 & 3 & 3 \\
Propilen glikol (g) & 1,5 & 1,5 & 1,5 & 1,5 \\
Air ad (mL) & 30 & 30 & 30 & 30
\end{tabular}

Keterangan: F1=konsentrasi 0\%, F2=konsentrasi 1\%, F3=konsentrasi 10\%, F4=konsentrasi $20 \%$.

Dalam pembuatan gel, semua bahan ditimbang terlebih dahulu sesuai dengan formula pada Tabel 1.
Pembuatan gel antiseptik tangan dari minyak atsiri daun cengkeh dengan konsentrasi $1 \%$ dilakukan dengan cara 
CMC-Na sebanyak 1,5 gram dalam minyak atsiri daun cengkeh yang dikembangkan di dalam mortir dengan berperan sebagai zat aktif dalam formula sedikit akuades panas, kemudian gel. Identifikasi ini dilakukan untuk dilakukan pengadukan secara terus menerus sehingga terdispersi sempurna dan terbentuk basis gel. Selanjutnya ditambahkan gliserin 3 gram, propilenglikol 1,5 gram dan sisa akuades sampai bobot gel $30 \mathrm{~mL}$ dengan terus dilakukan pengadukan hingga terbentuk gel dan ditambahkan minyak atsiri sebanyak 1\%. Untuk pembuatan gel dengan konsentrasi 0,10 , dan $20 \%$, dilakukan dengan cara yang sama. Setelah itu gel disimpan pada tempat yang gelap dan dingin di lemari pendingin $\left(10-15^{\circ} \mathrm{C}\right)$ sampai dilakukan pengujian. Pengujian yang dilakukan pada gel antiseptik tangan meliputi uji organoleptik, homogenitas, $\mathrm{pH}$, viskositas, daya sebar, daya lekat, dan uji daya hambat bakteri.

\section{Hasil dan Pembahasan}

Penelitian dimulai dengan
mengidentifikasi kandungan eugeno
memastikan bahwa minyak atsiri yang berasal dari Palu yang digunakan dalam pembuatan gel dalam penelitian ini benar mengandung eugenol yang menurut penelitian sebelumnya dinyatakan mempunyai aktifitas sebagai antibakteri (Nurdjannah, 2004). Analisis kandungan eugenol dilakukan menggunakan GC-MS (Harnani, 2010). Kromatogram GC-MS minyak atsiri daun cengkeh bisa dilihat pada Gambar 1. Sedangkan komponen-komponen penyusun minyak atsiri daun cengkeh dapat dilihat pada Tabel 2. Berdasarkan hasil dari analisis GC-MS dapat dilihat bahwa komponen terbanyak dalam minyak atsiri daun cengkeh adalah eugenol yang mencapai kadar 74,8\%. Hasil ini mendekati dari hasil penelitian sebelumnya yang menyatakan bahwa kandungan eugenol pada minyak atsiri daun cengkeh sebanyak 80-88\% (Zulchi dan Nurul, 2006). 


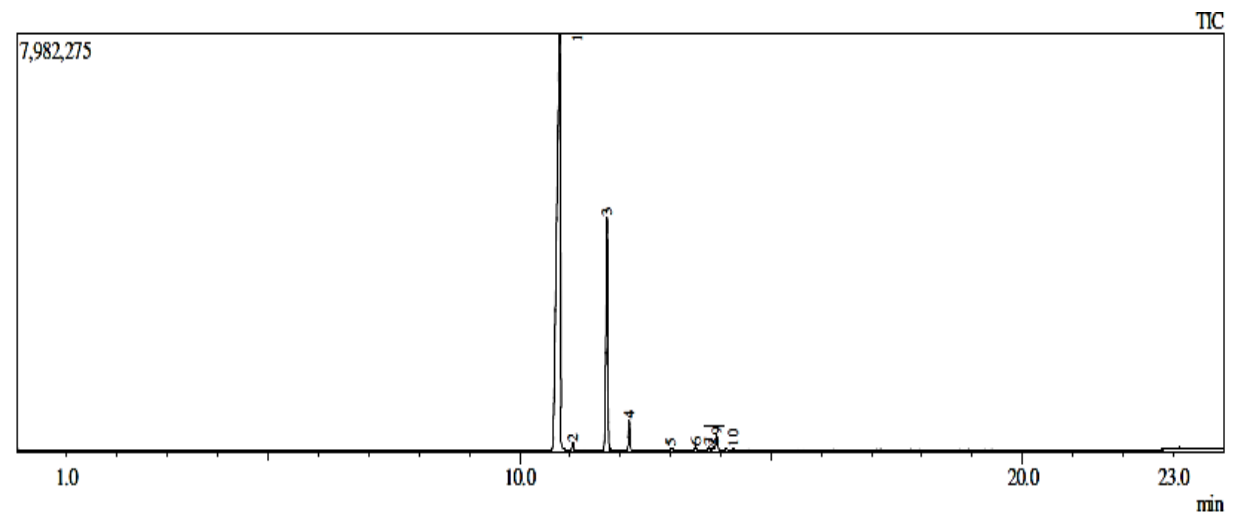

\begin{tabular}{rrrrrrr} 
& & & & \multicolumn{3}{c}{ Peak Report TIC } \\
Peak\# & R.Time & ITime & F.Time & Area & Area\% & Height \\
1 & 10.804 & 10.650 & 10.958 & 40003194 & 74.80 & 7954424 \\
2 & 11.063 & 10.958 & 11.117 & 353220 & 0.66 & 148655 \\
3 & 11.741 & 11.667 & 11.800 & 10605239 & 19.83 & 4448754 \\
4 & 12186 & 12.133 & 12.258 & 1210793 & 226 & 557582 \\
5 & 13.017 & 12.983 & 13.100 & 83124 & 0.16 & 29070 \\
6 & 13.502 & 13.458 & 13.558 & 148762 & 0.28 & 59441 \\
7 & 13.772 & 13.725 & 13.817 & 148297 & 0.28 & 52375 \\
8 & 13.854 & 13.817 & 13.883 & 175739 & 0.33 & 66291 \\
9 & 13.926 & 13.883 & 13.983 & 663685 & 1.24 & 283689 \\
10 & 14.250 & 14.158 & 14.300 & 87317 & 0.16 & 35824 \\
& & & & 53479370 & 100.00 & 13636105
\end{tabular}

Gambar 1. Hasil uji kromatografi gas minyak atsiri daun cengkeh.

Tabel 2. Kandungan minyak atsiri daun cengkeh dari Palu

\begin{tabular}{cll}
\hline No. Peak & BM & Nama Senyawa \\
\hline 1 & 164 & Eugenol \\
2 & 204 & Alpha-Copaene \\
3 & 204 & Beta-Caryophyllene \\
4 & 204 & Alpha- Humulene \\
5 & 204 & Naphthalene \\
6 & 220 & Caryophyllene oxide \\
7 & 194 & Tidak terdeteksi \\
8 & 220 & Caryophyllene oxide \\
9 & 220 & Caryophyllene oxide \\
10 & 220 & Caryophyllene oxide \\
\hline
\end{tabular}

Formulasi sediaan gel dilakukan berdasarkan formula pada Tabel 1 . Pengujian pertama yang dilakukan adalah uji organoleptik selanjutnya dilakukan uji-uji yang lain yaitu: daya sebar, daya lekat, dan viskositas. Perbedaan masing-masing formula yang ditunjukan pada Tabel 1 adalah berbeda 
dalam jumlah minyak atsiri yang digunakan.
Hasil
uji
organoleptik menunjukkan bahwa semua sediaan gel yang telah dibuat berbentuk setengah padat dengan aroma khas minyak atsiri daun cengkeh. Semakin tinggi konsentrasi minyak atsiri, semakin kuat aromanya, sementara basis gel yang dihasilkan hampir tidak berbau. Warna yang dihasilkan oleh gel minyak atsiri daun cengkeh dari semua variasi konsentrasi yaitu $0 \%$ berwarna putih, $1 \%$ berwarna kekuningan, 10 dan $20 \%$ berwarna kuning. Warna kuning yang semakin pekat disebabkan oleh kandungan minyak atsiri yang semakin tinggi.

Hasil pengujian homogenitas yang dilakukan selama 1 bulan dapat dilihat pada Tabel 3. Berdasarkan hasil pengamatan yang ditunjukan pada Tabel 3 , dapat dilihat bahwa formula 1 dan 2 selama satu bulan tidak mengalami perubahan. Pada minggu ke-2 untuk formula 3 mengalami perubahan yaitu sudah tidak homogen, dimana fase minyak terpisah. Sedangkan pada formula 4 sudah tidak homogen dari awal selesai pembuatannya. Gel pada formula 2, 3, dan 4 apabila didiamkan dalam jangka panjang akan mengalami pemisahan 2 fase. Fase atas menunjukkan minyak atsiri daun cengkeh yang bersifat lipofilik dan fase bawah menunjukkan basis gel yang sebagian besar bersifat hidrofilik, sehingga keduanya tidak saling bercampur

Tabel 3. Hasil uji homogenisitas gel selama 1 bulan

\begin{tabular}{cccccc}
\hline Formula & Minggu ke-0 & Minggu ke-1 & Minggu ke-2 & Minggu ke-3 & Minggu ke-4 \\
\hline 1 & Homogen & Homogen & Homogen & Homogen & Homogen \\
2 & Homogen & Homogen & Homogen & Homogen & Homogen \\
3 & Homogen & Homogen & Homogen & Tidak & Tidak \\
& & & & Homogen & Homogen \\
4 & Tidak & Tidak & Tidak & Tidak & Tidak \\
& Homogen & Homogen & Homogen & Homogen & Homogen \\
\hline
\end{tabular}

Pengujian yang kedua adalah pengujian $\mathrm{pH}$ dari gel. Dari hasil pengamatan uji $\mathrm{pH}$ didapatkan adanya perubahan $\mathrm{pH}$ dengan meningkatnya konsentrasi minyak atsiri daun cengkeh (Gambar 2). Setelah penyimpanan 
selama satu bulan, $\mathrm{pH}$ tetap stabil pada kisaran $\mathrm{pH}$ 4-6. Pada formula 1 dan 2 tidak bisa diterima oleh kulit karena mempunyai $\mathrm{pH}$ kurang dari 4,5; sedangkan untuk formula 3 mempunyai $\mathrm{pH}$ 5,0; dan formula 4 mempunyai $\mathrm{pH}$
6,0. Berdasarkan hasil dari penelitian Tranggono dan Latifa (2007) dapat disimpulkan bahwa hanya formula 3 dan 4 yang dapat diterima oleh kulit karena mempunyai kisaran pH antara 4,5-6,5.

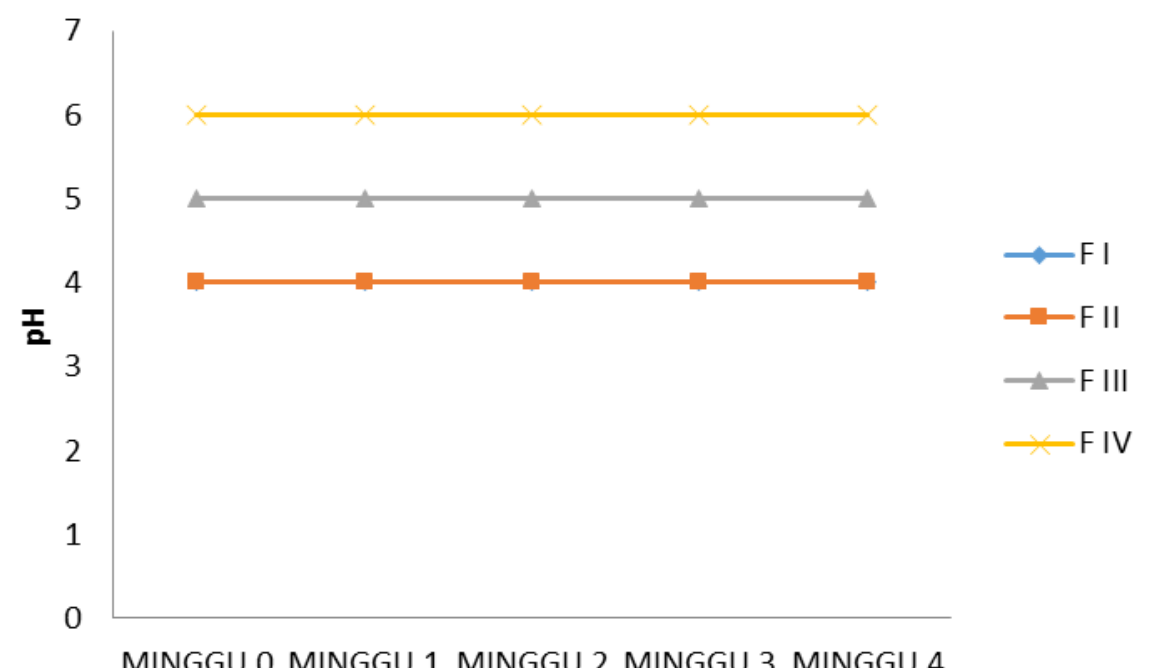

Gambar 2. pH gel selama satu bulan penyimpanan.

Hasil pengujian viskositas kecil viskositasnya. Penurunan nilai menunjukkan bahwa adanya variasi viskositas pada penyimpanan selama konsentrasi minyak atsiri daun cengkeh satu bulan disebabkan karena ikatan mempengaruhi viskositas sediaan gel antara penyusun gel semakin lemah (Gambar 3). Semakin tinggi konsentrasi yang bisa mengakibatkan turunnya minyak atsiri maka sediaan akan semakin viskositas (Arum, 2012). 


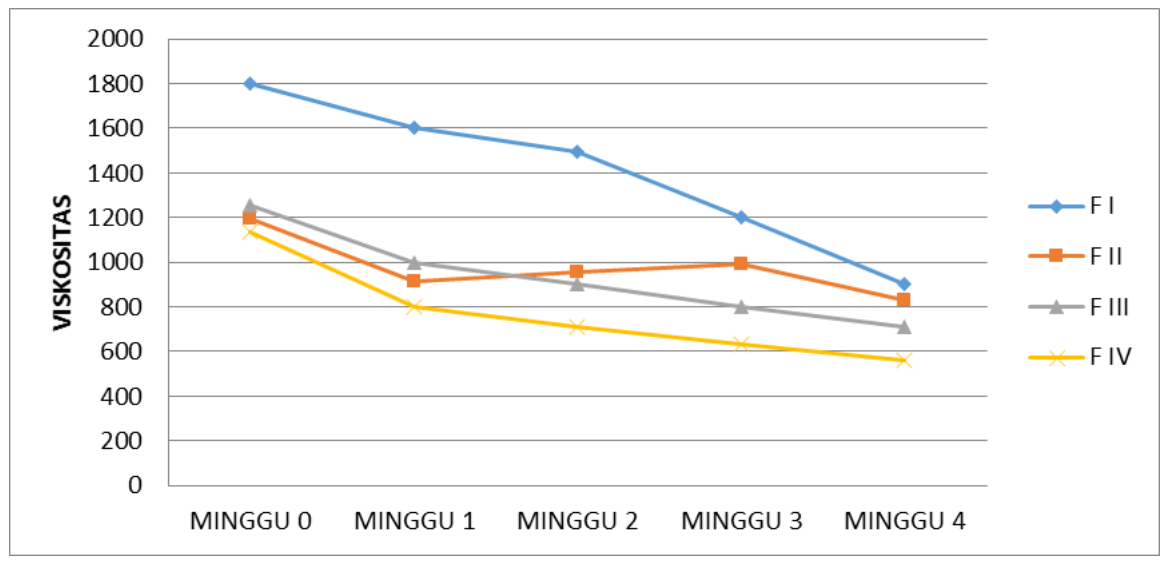

Gambar 3. Hasil dari uji viskositas selama satu bulan penyimpanan.

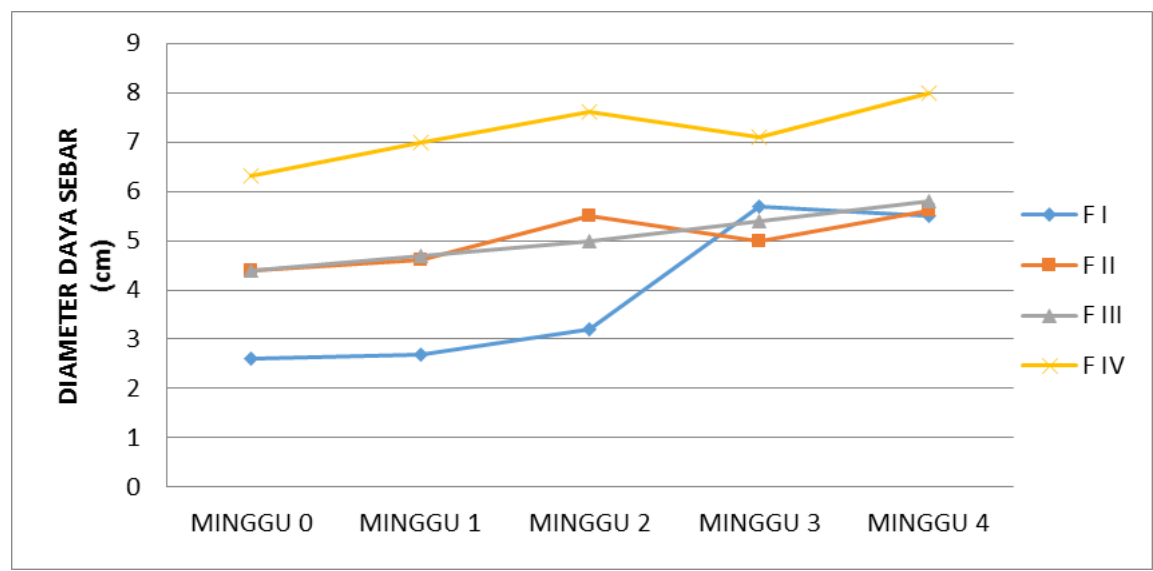

Gambar 4. Hasil uji daya sebar selama satu bulan penyimpanan.

Hasil uji daya sebar gel secara keseluruhan menunjukkan bahwa terjadi peningkatan diameter penyebaran gel, seiring dengan penambahan minyak atsiri. Penambahan minyak atsiri mempengaruhi kemampuan penyebaran gel karena viskositasnya yang semakin kecil. Semakin tinggi penambahan minyak atsiri akan menyebabkan diameter penyebaran semakin luas. Semakin lama penyimpanan gel, nilai daya sebarnya akan semakin besar, hal ini dikarenakan daya sebar gel dipengaruhi oleh viskositas sediaan. Selama penyimpanan satu bulan, viskositas sediaan semakin menurun sehingga menyebabkan daya sebarnya ikut berubah. 
Daya lekat gel dipengaruhi oleh viskositas gel (Gambar 5). Viskositas yang rendah karena penambahan minyak atsiri mengakibatkan waktu lekat yang singkat, karena gel ada pada keadaan encer dan tidak dapat melekat lebih lama. Dari Gambar 5 dapat dilihat bahwa semakin lama penyimpanan maka daya lekatnya akan semakin menurun.

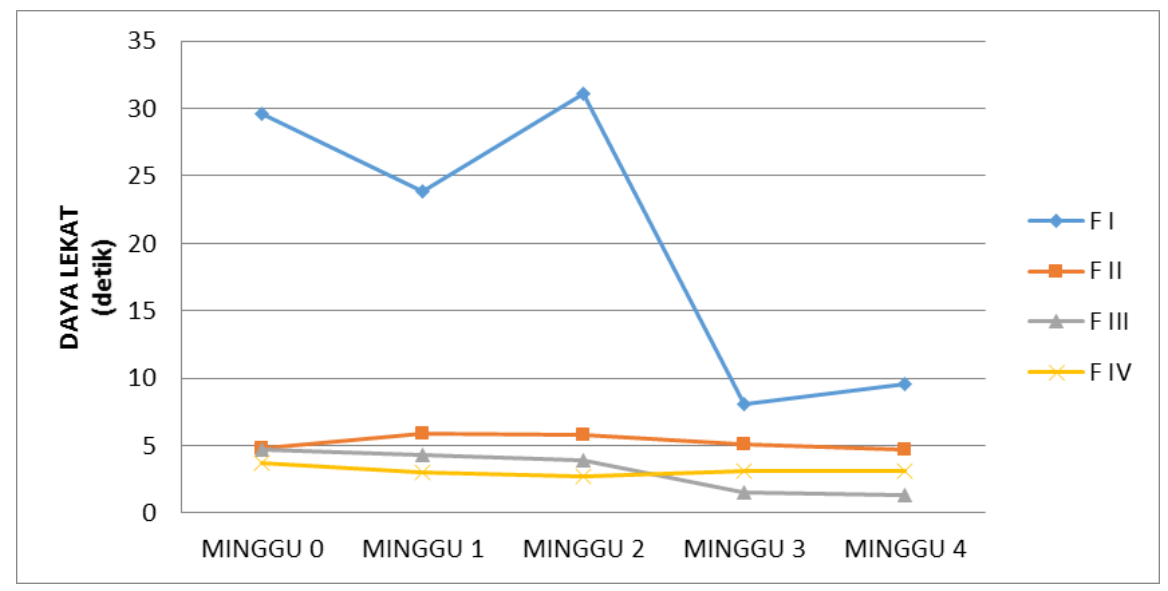

Gambar 5. Hasil uji daya lekat selama satu bulan.

\begin{abstract}
Hasil pengujian antimikorba yang menggunakan Staphylococcus aureus sebagai bakteri uji, menunjukkan bahwa minyak atsiri daun cengkeh setelah diformulasikan dalam gel dapat menghambat pertumbuhan bakteri Staphylococcus aureus dengan adanya zona hambat sebesar $12,5 \mathrm{~mm}$ pada formula 4 (Gambar 6).
\end{abstract}

Pemilihan Staphylococcus aureus sebagai bakteri uji dikarenakan bakteri ini merupakan flora normal yang sering dijumpai di tubuh manusia terutama di permukaan kulit. Tetapi dalam kondisi tertentu bisa menyebabkan infeksi (Masalha, 2001). Tabel 4 adalah tabel yang menunjukkan besarnya diameter zona hambat yang dihasilkan pada masing-masing formula. Bisa lihat bahwa semakin besar kadar minyak atsiri daun cengkeh, semakin kemampuan menghambat gel terhadap bakteri Staphylococcus aureus. Besar zona hambat yang dihasilkan pada formula 3 hampir mirip dengan besar zona hambat yang dihasilkan oleh kontrol positif. 
Dengan demikian bisa direkomendasikan adalah $10 \%$ apabila akan dilakukan konsentrasi minyak atsiri daun cengkeh produksi lebih lanjut.

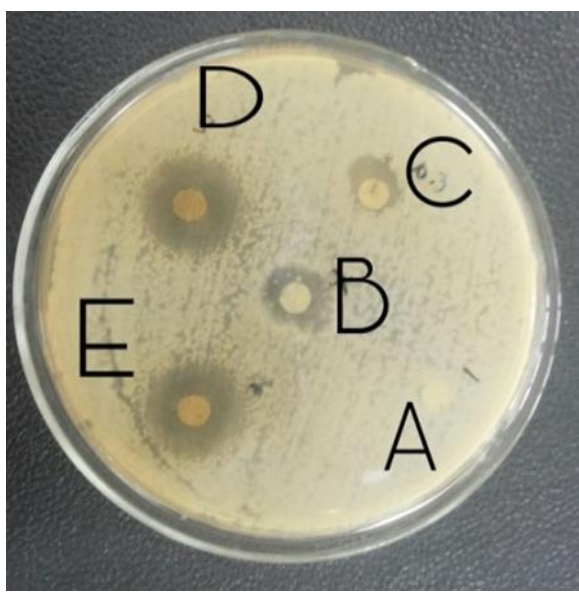

Gambar 4. Hasil uji antibakteri dimana A, B, C, D, dan E adalah berturut-turut kontrol negatif, kontrol positif, formula1, formula 2, formula 3, dan formula 4.

Tabel 4. Hasil uji mikrobiologi formulasi gel minyak atsiri daun cengkeh

\begin{tabular}{ccccc}
\hline \multirow{2}{*}{ Formula } & \multicolumn{3}{c}{ Diameter Zona Hambat $(\mathrm{mm})$} & \multirow{2}{*}{ Mean \pm SD } \\
\cline { 2 - 4 } & Replikasi I & Replikasi II & Replikasi III nn & \\
\hline Kontrol + & 4,5 & 11,5 & 3 & $6,3 \pm 4,5$ \\
F 1 & 0 & 0 & 0 & 0 \\
F 2 & 5 & 1 & 1 & $2,3 \pm 2,3$ \\
F 3 & 11 & 4,5 & 7 & $7,5 \pm 3,2$ \\
F 4 & 12 & 16,7 & 9 & $12,5 \pm 3,8$ \\
\hline
\end{tabular}

\section{Kesimpulan}

Peningkatan konsentrasi minyak atsiri daun cengkeh dalam sediaan gel mempengaruhi aktivitas antibakteri, daya sebar, daya lekat, dan viskositas pada sediaan gel antiseptik tangan minyak atsiri daun cengkeh. Sediaan yang paling optimal yaitu formula 3 dikarenakan $\mathrm{pH}$, daya sebar, daya lekat, uji viskositas, dan uji daya hambat sudah cukup untuk memenuhi standar antiseptik sediaan gel.

\section{Ucapan Terima Kasih \\ Penulis mengucapkan terima kasih yang sebesar-besarnya kepada}


Universitas Muhammadiyah Yogyakarta atas dukungan fasilitas laboratorium.

\section{Daftar Pustaka}

Arum, S.D. 2012. Formulasi gel antiseptik minyak atsiri daun sirih merah (Piper crocatum Rutz. \& Pav) dengan variasi penambahan natrium karboksimetilselulosa (Na-CMC) dan uji aktivitas antibakterinya. Skripsi. Fakultas Farmasi, Universitas Islam Indonesia.

Aiello, A.E., Coulborn, R.M., Perez, V.M.S, Larson, E.L. 2008. Effect of hand hygiene on infectious disease risk in the community setting: a meta-analysis. American Journal of Public Health, 98(8):1372-1381.

Bieri, F.A., Gray, D.J., Williams, G.M., Raso, G., Li, Y.S., Yuan, L., He, Y., Li, R.S., Guo, F.Y., Li., S.M. McManus, D.P. 2013. Health education package to prevent worm infections in Chinese school children. The New England Journal of Medicine, 368:1603-1612.

Biran, A., Schmidt, W.P., Varadharajan, K.S., Rajaraman, D., Kumar, R., Greenland, K., Gopalan, B., Aunger, R., Curtis, V. 2014. Effect of a behaviour-change intervention on handwashing with soap in India (SuperAmma): a cluster-randomised trial. The Lancet Global Health, 2(3):e145e154.

Curtis, V. dan Cairncross, S. 2003. Effect of washing hands with soap on diarrhoea risk in the community: a systematic review. The Lancet Infectious Diseaseas, 3(5):275-281.

Harnani, E.D. 2010. Perbandingan kadar eugenol minyak atsiri bunga cengkeh dari Maluku, Jawa, Sumatera, dan Sulawesi dengan Metode GCMS. Jurnal Farmasi Indonesia Pharmacon Pharmaceutical Journal of Indonesia, 11(1):25-32.

Luby, S.P., Agboatwalla, M., Feikin, D.R., Painter, J., Billhimer, W., Altaf, A., Hoekstra, R.M. 2005. Effect of handwashing on child health: a randomised controlled trial. Lancet, 366(9481):225-233.

Luby, S.P., Halder, A.K., Huda, T., Unicomb, L., Johnston, R.B. 2011. The effect of handwashing at recommended times with water alone and with soap on child diarrhea in rural Bangladesh: an observational study. PLOS Medicine, 8(6):e1001052.

Masalha, M., Borovok, I., Schreiber, R., Aharonowitz, Y., Cohen, G. 2001. Analysis of transcription of the Staphylococcus aureus aerobic class Ib and anaerobic class III ribonucleotide reductase genes in response to oxygen. Journal of Bacteriology, 183(24):7260-7272.

Maswadeh, H., Semreen, M., Naddaf, A. 2006. Anti-infalammatory activity of Achillea and Ruscus topical gel on carrageenan-induced paw edema in rats. Acta Poloniae Pharmaceutica-Drug Research, 63(4):277-280. 
Nurdjannah, N. 2004. Diversifikasi penggunaan cengkeh. Perspektif, 3(2):61-70.

Radji, M. 2010. Buku Ajar Mikrobiologi: Panduan Mahasiswa Farmasi dan Kedokteran. Jakarta: Penerbit Buku Kedokteran EGC.

Shu, M. 2013. Formulasi sediaan gel hand sanitizer dengan bahan aktif triklosan $0,5 \%$ dan $1 \%$. Calyptra: Jurnal Ilmiah Mahasiswa Universitas Surabaya, 2(1):1-14.

Tranggono, R.I. dan Latifah, F. 2007. Buku Pegangan Ilmu Pengetahuan Kosmetik. Jakarta: PT. Gramedia.

Umar, Z. 2008. Perilaku cuci tangan sebelum makan dan kecacingan pada murid SD di Kabupaten Pesisir Selatan Sumatera Barat. Jurnal Kemas, 2(6):249-254.

Zulchi, T.P.H., Nurul, A.R. 2006. Pengaruh Berbagai Organ Tanaman dan Lama Penyulingan terhadap Kuantitas dan Kualitas Minyak Atsiri Cengkeh (Caryophillus aromaticus). http://digilib.itb.ac.id/gdl.php?mo $d=$ browse\&op=read\&id=jiptummgdlres-2002-try-5372atsiri\&q=Minyak. Diakses tanggal 1 November 2015. 